\title{
Thermozyme Amylase from Enterobacter sp Extremophiles in Bioethanol Production
}

\author{
Gustina Indriati ${ }^{1}$, Ruth Rize Paas Megahati S..$^{*}$ \\ ${ }^{1}$ Hiperkes and Work Safety Study Program, STIKES Indonesia, Padang, West Sumatra, Indonesia \\ ${ }^{2}$ Biology Department STKIP PGRI Sumatera Barat, Padang, West Sumatra, Indonesia
}

DOI: $10.29303 /$ jossed.v2i1.698

\section{Article Info}

Received : January 25th, 2021

Revised : April 10th 2021

Accepted: April 21th, 2021

\begin{abstract}
Bioethanol is an alternative fuel to replace fossil fuels due to the reduction of fossil fuels. Bioethanol is produced from starch and converted to sugar by thermozyme amylase. Thermozyme amylase produced by thermophile bacteria can be obtained from Pariangan hot springs which have a temperature of $55^{\circ} \mathrm{C}, \mathrm{pH}$ of 9.2 , and have a high level of bacterial diversity. The aim of this study was to obtained isolates of thermozyme amylase-producing bacteria that have the potential for bioethanol production. The research method were bacteria isolation, amylase stability test, temperature and $\mathrm{pH}$ optimization, and bioethanol production. The result showed that Enterobacter $\mathrm{sp}$ has been isolated from Pariangan hot springs is stable up to 5 hours of incubation, temperature and $\mathrm{pH}$ optimum was $85^{\circ} \mathrm{C}, \mathrm{pH}$ 8.5 , and fructose as a carbon source. Thermozyme amylase converts starch into sugar under optimum conditions with a yield of $9.8 \%$ bioethanol.
\end{abstract}

Keywords: amylase; bioethanol; extremophiles; Enterobacter sp; Pariangan Hot Spring

Citation: Indriati, G., \& Megahati, R. (2021). Thermozyme Amylase from Enterobacter sp Extremophiles in Bioethanol Production. Journal of Science and Science Education, 2(1), 1-7. doi:https://doi.org/10.29303/jossed.v2i1.698

\section{Introduction}

Amylase produced by bacteria or bacteria amylase is an enzyme that can hydrolyze starch to sugar (Megahati et al 2017). Amylase can convert starch to sugar in bioethanol production. Bioethanol is a biofuel that is renewable and environmentally friendly (Fatoni, \& Zulfahair. 2012). Bioethanol is an alternative fuel to replace fossil fuels due to the reduction of fossil fuels (Svetlitchnyi et al., 2013). Bioethanol is used as a gasoline mixture to become biofuel. The composition of bioethanol in gasoline in the world has $5 \%$ in 2020 and increased by $20 \%$ in 2025 .

Generally, bioethanol is produced from starch and converted to sugar by thermozyme amylase. As a thermozyme, amylase generally does not undergo denaturation and is active at high temperatures and is very stable at normal temperatures (Schiraldi, \& Rosa, 2002). Thermozyme amylase is one of the three largest industrial group enzymes and accounts for approximately $65 \%$ of the world enzyme (Abdullah et al, 2014). Thermophile bacteria are commonly found in volcanic craters, craters on the ocean floor, and hot springs. Some hot springs in Indonesia generally have a $\mathrm{pH}$ of 7 or even below 7 or are acidic. In contrast to the Pariangan hot springs which have a temperature of 47 ${ }^{\circ} \mathrm{C}-51{ }^{\circ} \mathrm{C}$ and a $\mathrm{pH}$ of 9.2. This causes Pariangan hot springs to have a high level of bacteria diversity. The aim of this study was to obtained isolates of thermozyme amylase-producing bacteria that have the potential for bioethanol production. Bioethanol as a biofuel is needed as an alternative fuel to reduce the use of fossil fuels. Bioethanol can be obtained by utilizing the potency of thermophile amylase-producing bacteria which will be carried out in this study. The success of this research is a finding/innovation that can be applied in the development and development of science and technology. 


\section{Method}

\section{Isolation and screening of bacteria}

A hot water sample was poured into the medium NA $((20 \mathrm{~g} / \mathrm{l}))$ and incubated for 24 hours at 50 ${ }^{\circ} \mathrm{C}$. Bacteria growing on the NA medium were transferred into the selective medium $(10 \mathrm{~g} / 1$ starch and $15 \mathrm{~g} / 1$ agar) and incubated at $50{ }^{\circ} \mathrm{C}$ for 24 hours. Growing bacteria colonies are selected by pouring iodine solution around the bacteria colony.

\section{Production and amylase activity}

Bacteria were planted in $25 \mathrm{ml}$ of basal medium pH $7.5\left(3 \mathrm{~g} / 1 \mathrm{KH}_{2} \mathrm{PO}_{4}, 3 \mathrm{~g} / 1 \mathrm{~K}_{2} \mathrm{HPO}_{4}, 5 \mathrm{~g} / 1 \mathrm{~K}_{2} \mathrm{HPO}_{4}, 5 \mathrm{~g} / 1\right.$ $\mathrm{NaCl}, 10 \mathrm{~g} / 1 \mathrm{starch}$ ) and were agitated at a speed of 150 rpm for 24 hours at $50{ }^{\circ} \mathrm{C}$. $5 \%$ of bacterial culture was transferred to $50 \mathrm{ml}$ of the new basal medium $\mathrm{pH} 7.5$ and growth was followed by absorbance measurements at $540 \mathrm{~nm}$. The growing bacteria culture was centrifuged at a speed of $5000 \mathrm{rpm}$ for 5 minutes. The cell pellets were resuspended with $3 \mathrm{ml}$ sucrose solution $0,3 \mathrm{M} ; 0.1 \mathrm{M}$ Tris HCL pH 8.5 ; and $0.2 \mathrm{mg} / \mathrm{ml}$ lysozime. The suspension was shaken with vortex for 1 minute and incubated for 30 minutes in ice. The suspension was centrifuged for 20 minutes at a speed of $15000 \mathrm{rpm}$ at 4 ${ }^{\circ} \mathrm{C}$. The supernatant produced is crude amylase enzyme whose activity will be tested. Amylase activity assay was determined according to the Samogy-Nelson methods (Nelson, 1974).

\section{Amylase stability test}

The amylase produced by the three bacterial isolates was incubated at $50{ }^{\circ} \mathrm{C}$ with varying incubation times (0-8 hours) and the amylase activity was measured. Bacteria that have the most stable amylase will be used in this study.

\section{Morphological characterization and biochemical} properties of bacteria isolates

Bacteria characterization was carried out by observing the bacteria's cell shape and Gram staining. Biochemical properties are carried out by performing several biochemical tests such as Catalase, Oxidase, TSIA, Urea, Citrate, Indole, Lactose, Glucose, Sucrose, Mannitol, MR, VP, OF, Arabinose, Nitrate, and Gelatin (Cowan \& Steel's, 1974).

\section{Temperature Optimization}

Bacteria were planted in $50 \mathrm{ml}$ of basal medium pH $7.5\left(3 \mathrm{~g} / 1 \mathrm{KH}_{2} \mathrm{PO}_{4}, 3 \mathrm{~g} / 1 \mathrm{~K}_{2} \mathrm{HPO}_{4}, 5 \mathrm{~g} / 1 \mathrm{~K}_{2} \mathrm{HPO}_{4}, 5 \mathrm{~g} / 1\right.$ $\mathrm{NaCl}, 10 \mathrm{~g} / 1 \mathrm{starch}$ ) and were agitated at a speed of 150 rpm for 24 hours at $50{ }^{\circ} \mathrm{C}$. $5 \%$ bacterial culture was transferred to $100 \mathrm{ml}$ of a new basal medium $\mathrm{pH} 7.5$ and agitated at a speed of $150 \mathrm{rpm}$ for 10 hours at various temperatures $\left(60^{\circ} \mathrm{C}-95^{\circ} \mathrm{C}\right)$. The growing bacteria culture was centrifuged at a speed of $5000 \mathrm{rpm}$ for 5 minutes, the supernatant containing amylase was tested for its thermozyme amylase activity.

\section{pH Optimization}

Bacteria were planted in $50 \mathrm{ml}$ of basal medium $\mathrm{pH} 7.5\left(3 \mathrm{~g} / 1 \mathrm{KH}_{2} \mathrm{PO}_{4}, 3 \mathrm{~g} / 1 \mathrm{~K}_{2} \mathrm{HPO}_{4}, 5 \mathrm{~g} / 1 \mathrm{~K}_{2} \mathrm{HPO}_{4}, 5\right.$ $\mathrm{g} / 1 \mathrm{NaCl}, 10 \mathrm{~g} / 1$ starch) and were agitated at a speed of $150 \mathrm{rpm}$ for 24 hours at $50{ }^{\circ} \mathrm{C}$. The $5 \%$ bacteria culture was transferred to $100 \mathrm{ml}$ of a new basal medium with varying $\mathrm{pH}$ (7.0-9.5) and agitated at a speed of $150 \mathrm{rpm}$ for 10 hours at the optimum temperature (the result of temperature optimization at stage 1). The growing bacteria culture was centrifuged at a speed of $5000 \mathrm{rpm}$ for 5 minutes, the supernatant containing amylase was tested for its thermozyme amylase activity.

\section{Carbon Sources}

Source of carbon (fructose, sucrose, lactose, and glucose) with a concentration of $1 \%$ added to the production medium $\mathrm{pH} 8.5$ and shaker at $150 \mathrm{rpm}$ with a temperature of $50^{\circ} \mathrm{C}$ for 24 hours. The $5 \%$ bacteria culture was transferred to $100 \mathrm{ml}$ of a new basal medium with varying $\mathrm{pH}(8.5)$ and agitated at a speed of $150 \mathrm{rpm}$ for 10 hours at the optimum temperature (the result of temperature optimization at stage 1). The growing bacteria culture was centrifuged at a speed of $5000 \mathrm{rpm}$ for 5 minutes, the supernatant containing amylase was tested for its thermozyme amylase activity.

\section{Bioethanol production}

Cassava has been crushed into a cooker tank and the liquefaction process is carried out at a temperature of $80^{\circ} \mathrm{C}-85^{\circ} \mathrm{C}$ by adding $5 \mathrm{ml}$ of thermozyme amylase. The saccharification is carried out at a temperature of 55 ${ }^{\circ} \mathrm{C}$ and inserted $2.5 \mathrm{ml}$ of glucoamylase and then stirred evenly. The saccharification is carried out at $37^{\circ} \mathrm{C}$ and fermentation are carried out by inserting 20 grams of Urea fertilizer and 5 grams of NPK fertilizer into the saccharified liquid. After stirring evenly, add 15 grams of Saccharomyces cerevisiae. Cover the fermentor tightly for 7 days and the fermentation process will occur anaerobically. Distillation is carried out using a fractional distillator (multi-level column) with the reflux column system technique. The distillation process is carried out at a temperature of $78{ }^{\circ} \mathrm{C}$. Ethanol vapor in the distillator flow to the condenser so that it is condensed into bioethanol liquid.

\section{Result and Discussion}

\section{Isolation and screening of bacteria}

Three isolates of thermozyme amylase-producing bacteria have been obtained from 16 isolates that have 
been successfully isolated in the Pariangan hot spring. This is shown by the formation of clear zones around bacteria growth (Figure 1).

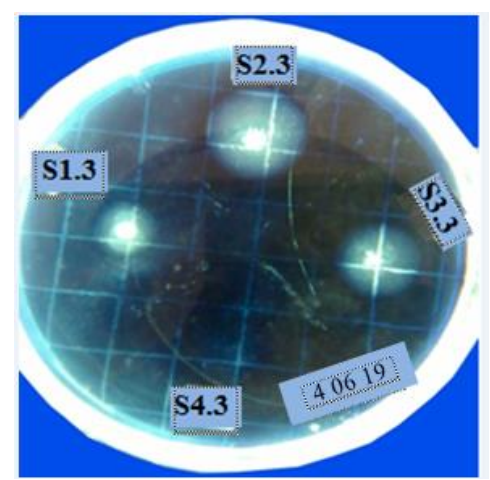

Figure 1. Clear zones around bacteria growth

The clear zone is formed as a result of the hydrolysis of starch by thermozyme amylase produced by bacteria. The media surrounding S4.3 bacteria isolate that does not produce thermozyme amylase will be blue when iodine solution drops. This shows that the starch in the medium is not degraded to simple sugars which means that bacteria do not produce thermozyme amylase (Megahati, 2018).

\section{Production and amylase activity}

The results of the thermozyme amylase activity test for the three bacteria isolates showed that the S2.3 bacteria isolate had the highest specific activity, namely $465.8 \mathrm{U} / \mathrm{mg}$ (Figure 2). The difference in amylase activity was due to the fact that the S2.3 bacteria isolates were better able to degrade starch than the S1.3 and S3.3 isolates.

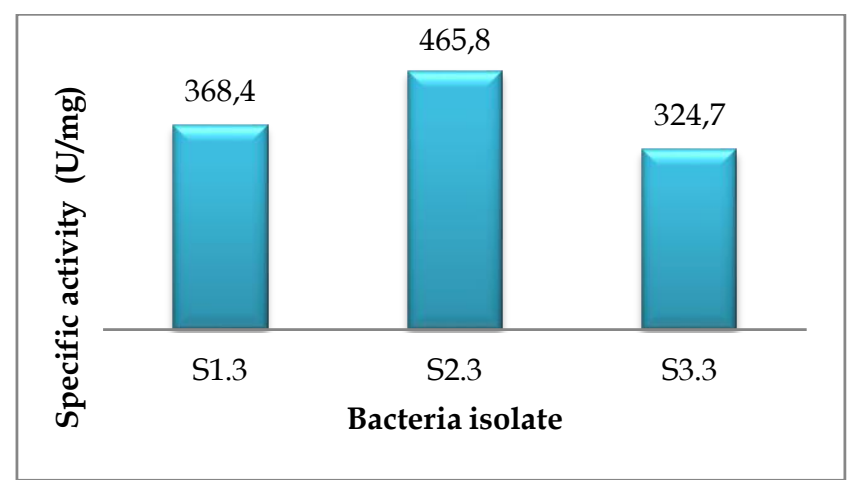

Figure 2. Specific activity of S2.3 isolate bacteria

The difference in enzyme activity in each isolate is caused by the amount and activity of the enzyme secreted from each isolate (Agustien, 2005). Screening and testing for amylase activity were also conducted by Arfah et al, (2015) who obtained R-SAII-1b isolates from hot springs Lejja (South Sulawesi) with an activity of $0.0711 \mathrm{U} / \mathrm{mg}$ protein.

\section{Amylase stability test}

The amylase stability test on the three thermophile bacteria isolates showed that the amylase produced by the S2.3 bacteria isolate was more stable than the amylase produced by the S1.3 and S3.3 bacteria isolates (Figure 3). Amylase produced by the S2.3 bacteria isolates was $100 \%$ stable until the fifth hour of incubation (temperature $50^{\circ} \mathrm{C}$ ) while at the sixth to eight hours the amylase lost its stability.

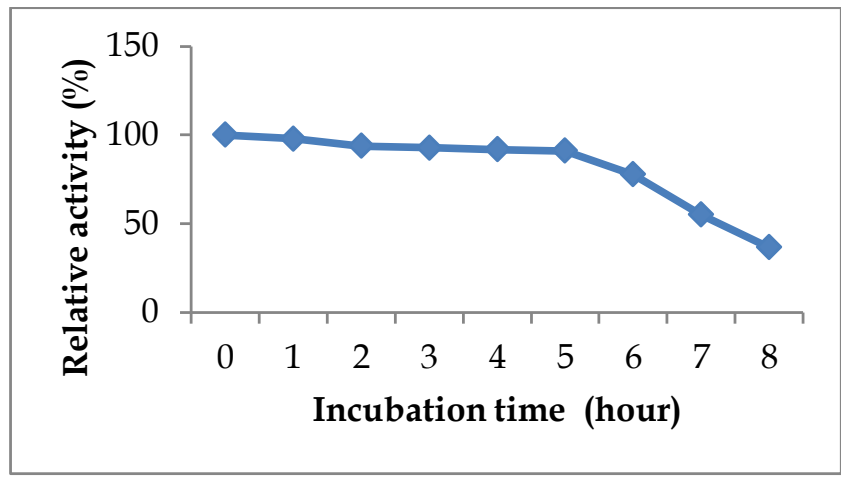

a) Amylase stability of bacterial isolates S1.3

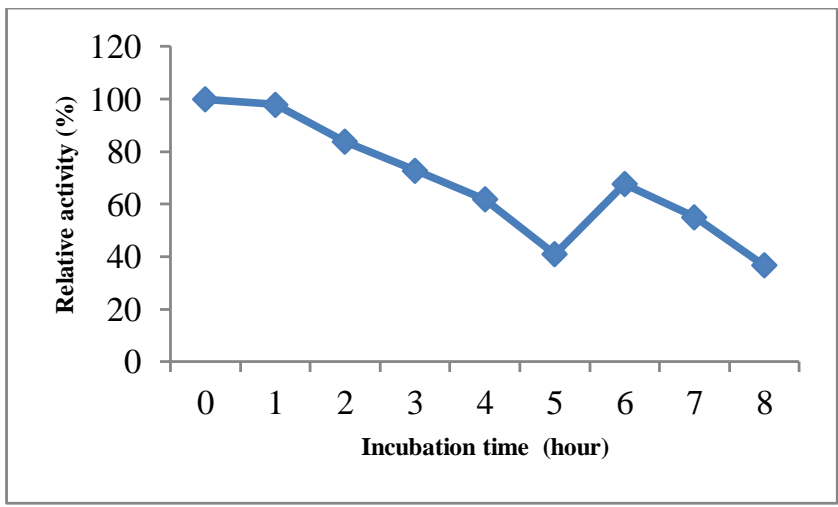

b) Amylase stability of bacterial isolates S1.3

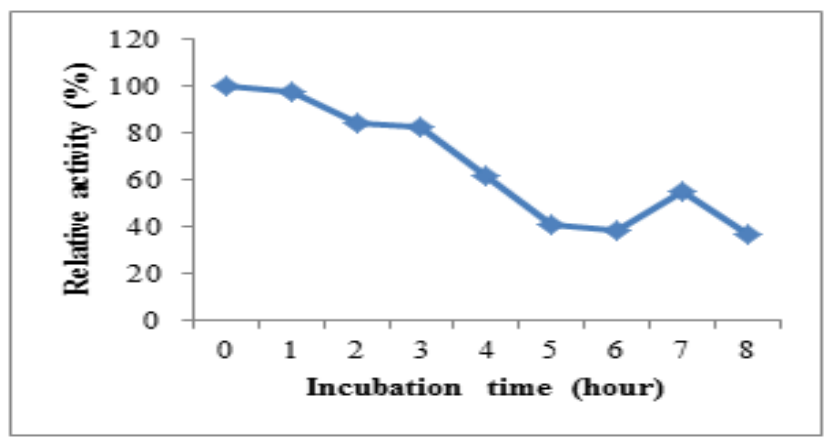

c) Amylase stability of bacteria isolates S3.3

Figure 3. Amylase stability of bacteria isolate S2.3, S1.3, and S3.3

Amylase produced by bacteria isolates S1.3 and S3.3 is unstable, this can be seen from the fluctuating amylase activity. This is thought to be due to the influence of chaperonin, chaperonin is a functional 
protein that plays a role in retaining the threedimensional structure of proteins from denaturation of extreme environmental temperatures (Kumar \& Nussinov, 2001). The amylase stability of Bacillus sp AB68A was $60 \%$ stable for 60 minutes of incubation at 50 ${ }^{\circ} \mathrm{C}$ (Aygan et al., 2008). The stability of proteins or enzymes is influenced by different factors from each taxon, organism, and even the same organism. Protein stability will vary in each organism even though these organisms come from the same environment (Kumwenda et al., 2013). Likewise, the S2.3 bacterial isolate was more stable than the amylase from other bacteria isolates even though it came from the same hot spring. Therefore S2.3 bacteria isolate will be used for research in bioethanol production.

\section{Morphological characterization and biochemical test of bacteria isolates}

Based on the results of morphological characterization and biochemical test of bacteria isolates shown that S2.3 isolate belonging to Enterobacter sp (Table 1). According to Cowan \& Steel's (1974) Enterobacter sp is a group of Gram-negative rod-shaped bacteria, is aerobic and facultative anaerobic, capable of producing gas, on a positive motility test. Enterobacter $\mathrm{sp}$ from Pacet hot springs, Mojokerto, Indonesia can produce amylase with high activity (Sari, 2016).

Table 1. Morphology and biochemical properties test results

\begin{tabular}{|c|c|c|}
\hline \multirow[t]{2}{*}{ No } & \multirow{2}{*}{$\begin{array}{l}\text { Test of morphology } \\
\text { and biochemical } \\
\text { properties }\end{array}$} & Results \\
\hline & & S2.3 isolate \\
\hline 1 & $\begin{array}{l}\text { Colony } \\
\text { characteristic }\end{array}$ & $\begin{array}{l}\text { Yellowness colored, rounded } \\
\text { shape, flat smooth, and flat } \\
\text { elevation }\end{array}$ \\
\hline 2 & Gram staining & Gram-negative \\
\hline 3 & Endospores & Positive \\
\hline 4 & Cell shape & Bacillus \\
\hline 5 & Catalase & + \\
\hline 6 & TSIA & Red/yellow \\
\hline 7 & Oxidase & + \\
\hline 8 & Indole & + \\
\hline 9 & Urea & - \\
\hline 10 & Citrate & + \\
\hline 11 & Lactose & + \\
\hline 12 & Glucose & - \\
\hline 13 & Sucrose & - \\
\hline 14 & Mannitol & + \\
\hline 15 & MR & + \\
\hline 16 & $\mathrm{VP}$ & + \\
\hline 17 & OF & - \\
\hline 18 & Arabinose & + \\
\hline 19 & Nitrate & - \\
\hline
\end{tabular}

\begin{tabular}{lll}
\hline No & $\begin{array}{l}\text { Test of morphology } \\
\text { and biochemical } \\
\text { properties }\end{array}$ & Results \\
\cline { 3 - 3 } & S2.3 isolate & \\
\hline 20 & Gelatine & - \\
21 & Xylose & - \\
\hline & Genus proposed & Enterobacter sp \\
\hline
\end{tabular}

Enterobacter sp is found in various places, such as in soil, hot springs, and seawater sediments. Enterobacter is rod-shaped, Gram-negative, anaerobic facultatively, and contains peritrichous flagella. This is oxidase-negative and catalase-positive (Streit, 2004).

\section{Bacteria Growth Curve}

The optimum time for thermozyme amylase activity and Enterobacter sp growth was obtained through a bacteria growth curve. Bacteria growth increased at eight hours followed by an increase in specific amylase activity of $27.64 \mathrm{U} / \mathrm{mg}$ (Figure 4 ). At the tenth hour of bacterial death followed by a decrease in amylase activity.

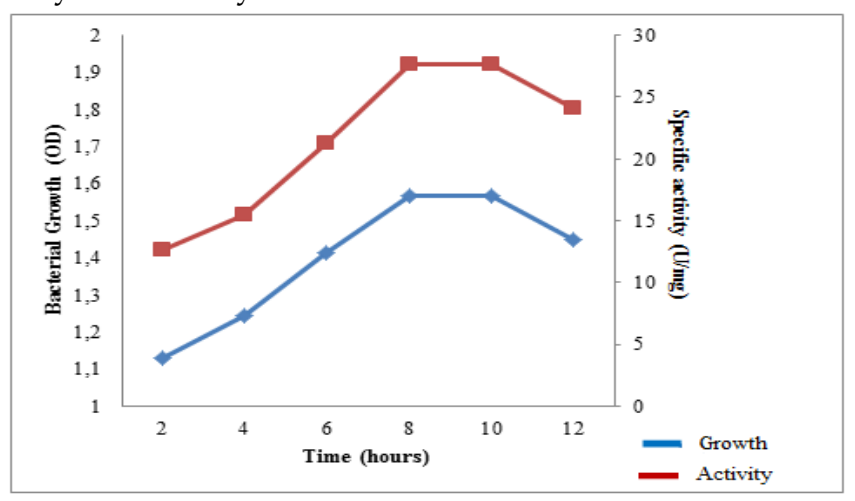

Figure 4. Time of bacterial growth and S2.3 isolate amylase production

Optimum growth and amylase activity of Anobaxycillus sp. IB-A occurs at 48 hours (stationary) after which the bacterial isolate goes to the death phase (Hauli et al., 2013). Increasing the incubation time decreases amylase production. This is due to reduced nutrients, accumulated toxicity in the medium, amylase proteolysis, and microorganisms (Yang \& Liu, 2004).

\section{Temperature optimization}

The results of temperature optimization on amylase activity showed an increase in amylase specific activity at $85^{\circ} \mathrm{C}$ which is $487.6 \mathrm{U} / \mathrm{mg}$ because it is the temperature suitable for the growth of bacteria for amylase production (Figure 5). An increase in incubation temperature above $85{ }^{\circ} \mathrm{C}$ will cause a decrease in amylase activity. 


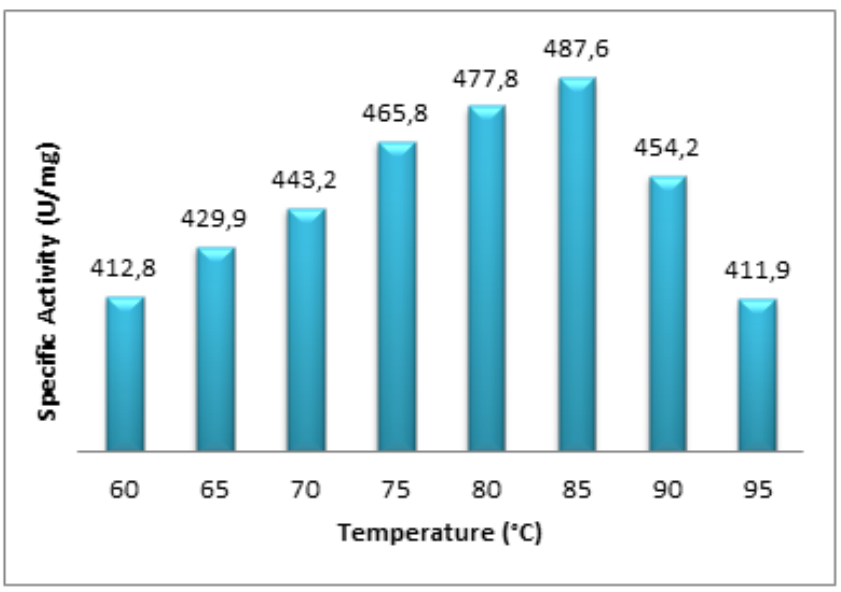

Figure 5. The effect of temperature to amylase production

This is caused by the amylase denaturation which causes amylase conformation change. Activity enzymes increase with increasing temperature of the growth medium to achieve optimum enzyme activity (Pelczar, 1988). The effect of temperature on amylase production is related to growth bacteria (Lehninger, 1982).

\section{pH Optimization}

Increasing the $\mathrm{pH}$ will increase the amylase activity up to reach the optimum $\mathrm{pH}$. The $\mathrm{pH}$ of the production medium above $\mathrm{pH} 8.5$ is caused by decreased amylase activity (Figure 6). Decreased amylase production above $\mathrm{pH} 8.5$ caused by a change in the environmental conditions of the enzyme, where the $\mathrm{pH}$ an alkaline enzyme environment will cause an increase in concentration $\mathrm{OH}^{-}$in the enzyme environment (Asgher et al., 2007).

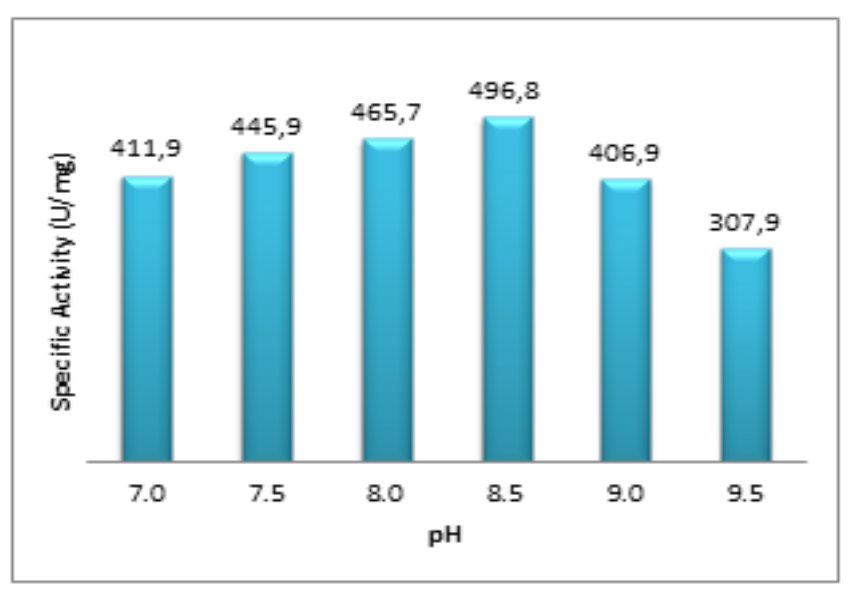

Figure 6. The effect of $\mathrm{pH}$ to amylase production

Each bacteria has a growth medium with the right $\mathrm{pH}$ because the $\mathrm{pH}$ of the media plays a role in morphological changes and enzyme secretion (Megahati, 2018). Each bacteria has an optimum growth media $\mathrm{pH}$ for the growth and production of the enzyme with the highest activity (Nwagu \& Okolo, 2011).

\section{Carbon Sources}

Carbon sources (fructose) can increase amylase production compared to other carbon sources (Figure 7). According to (Mei \& Chen, 2007; Sudarhsan et al., 2007) fructose is a good source of carbon in increasing amylase production. Fructose and glucose are very effective in stimulating bacterial growth and respiration (Choubane et al., 2015). Meanwhile, according to Hasan \& Hameed, (2001), lactose can increase the activity and production of amylase compared to glucose, fructose, and sucrose. Glucose is efficient in producing amylase from Bacillus thermooleovoran (Belal et al., 2015). Carbon sources have an important role in providing nutrients and energy sources to bacteria.

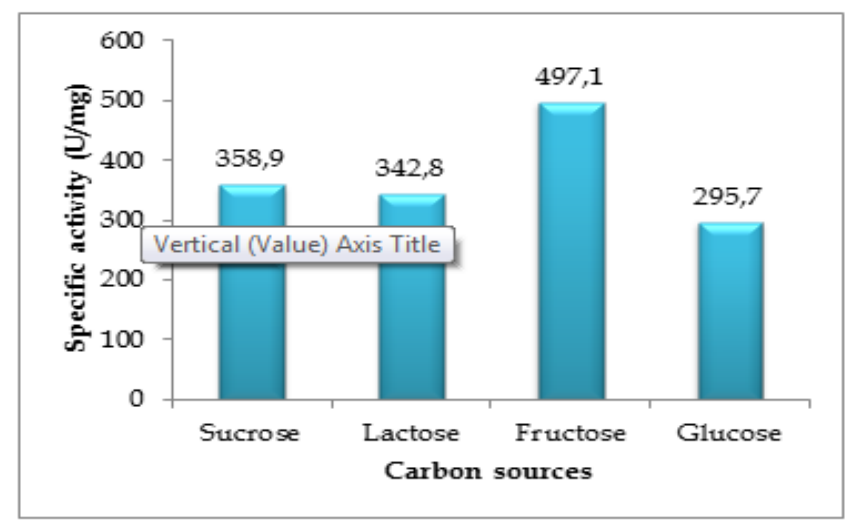

Figure 7. Effect of carbon sources on thermozyme amylase production

The addition of carbon sources to the production medium plays a role in enriching the formation of amino acids and gases from carbon sources (Hasan \& Hameed, 2001).

\section{Bioethanol production}

Generally, bioethanol is produced from the basic ingredients of starch (Cassava) and converted to sugar by amylase. Biological conversion of biomass into bioethanol by utilizing the potential of extremophiles is preferred because it will save production costs. Bioethanol distillation using a fractional distillator (multi-level column) with the reflux column system technique produces bioethanol with a concentration of $9.8 \%$. Utilizing the potential of amylase in converting starch from potato waste for bioethanol production and obtaining bioethanol at a concentration of $9.6 \%$ (Belal et al., 2015). This shows that the amylase produced by Enterobacter sp has the potential to produce bioethanol. Bioethanol as a biofuel is needed in the world, especially in Indonesia as an alternative fuel to reduce the use of fossil fuels (Svetlitchnyi et al., 2013). If the use of fossil 
fuels is not controlled, it can cause the depletion of petroleum supplies.

\section{Conclusion}

Thermozyme amylase is stable up to 5 hours of incubation, temperature, and $\mathrm{pH}$ optimum was $85^{\circ} \mathrm{C}$, 8.5, and fructose as carbon sources. Thermozyme amylase converts starch into sugar under optimum conditions with a yield of $9.8 \%$ bioethanol.

\section{Acknowledgments}

The author would like to thank The Directorate General of Higher Education DRPM, the Republic of Indonesia for funding this research.

\section{References}

Abdullah, J.R., Shaheen, N., Iqtedar, M., Naz, S., \& Iftikhar, N.( 2014). Optimization of cultural conditions for the production of alpha-amylase by Aspergillus niger (BTM-26) in solid-state fermentation. Pakistan Journal of Botany, 46(3), 1071-1078. Retrieved from https://inis.iaea.org/search/searchsinglerecord. aspx? recordsFor $=$ SingleRecord \&RN $=45090273$

Agustien, A. (2005). Isolasi dan Karakterisasi Enzim Amilase Termostabil dari Bakteri Isolat Sumbar. Project Report. Lembaga. Penelitian Universitas Andalas.

Arfah, R. A., Ahmad, A.N., Djide, M., Anis. and Zakir, M. (2015). Production optimation and characterization of amylase enzyme isolated from termophile bacteria Bacillus sp RSAII-1b from Lejja hot spring South Sulawesi. American Journal of Biomedical and Life Science,3(6), 115-119. Retrieved from http://article.sciencepublishinggroup.com/html L10.11648.j.ajbls.20150306.13.html

Asgher, M., Javaid, M., Asad, S. U., Rahman, R. L. and Legge. (20070. A thermostable a-amylase from a moderately thermophilic Bacillus subtilis for starch processing. Journal of Food Engineering, 79, 950-955.

Aygan, A., Arikan, B., Korkmaz, H.,.Dincer, S. and Colak, O. (2008). Highly thermostable and alkaline a-amylasee from a halotolerantalkaliphilic Bacillus sp. AB 68. Brazilian Journal of Microbiology, 39, 547-553.

Belal, E. B., Mona, A., Farid. and Sosha, A. A. A. (2015). Production of bioethanol via microbial and enzymatic hydrolysis of potato wastes under solid state fermentation. International Journal of Current Microbiology and Applied Sciences, 4(7), 511524.
Choubane, S., Khelil, O. and Cheba, B. A. (2015). Bacillus sp. R2 a-amylase production optimization: pasta cooking water as a medium of amylase production. African Journal of Biotechnology, 14(47), 3184-3189.

Cowan, S.T., \& Steel's. (1974). Manual for The Identification of Medical Bacteria. Cambridge University Press: Landon, New York, Melbourne.

Fatoni, A., \& Zulfahair. 2012. Thermophilic Amylase from Thermus sp. Isolation and its potential application for bioethanol production. Songklanakarin Journal of Science and Technology, 34(5), 525-531. Retrieved from https://rdo.psu.ac.th/sjstweb/journal/345/0475-3395-34-5-525-531

Hasan, F., \& Hameed, A. (2001). Optimization of lipase production from Bacillus sp. Pakistan Journal of Botany, 33, 789-796.

Hauli, I., Sarkar, B., Mukherjee, T., Mukhophaday, S. K. (2013). Isolation and identification of a novel thermo-alkaline, thermostable, SDS, and chelator resistant amylase producing Anoxybacillus sp. IBA from hot spring of Bakreswar, West Bengal (India): First report. Pelagia Research Library, 4(5), 202-2012.

Kumar, S., \& Nussinov, R. (2001). How do thermophilic proteins deal with heat?. Cellular and Molecular Life Science, 58 (9), 1216-1233.

Kumwenda, B., Litthauer, D., Bishop, O. T. and Reva, O. (2013). Analysis of protein thermostability enhancing factors in industrially important Thermus Bacteria species. Evolutionary informatics, 9, 327-342.

Lehninger, A. L. (1982). Dasar-Dasar Biokimia Jilid I. Terjemahan Maggy Thenawidjaja. Erlangga: Jakarta.

Megahati, R.R.P. (2018). Molecular identification (16S $r R N A)$ gene of amylase producing-bacteria. Germany: Lambert Academic Publishing

Megahati, R.R.P., Mansyurdin.., Agustien, A., \& Tjong, D.H. (2017). Optimization of bacteria amylase activity from Bacillus licheniformis strain SEM11. International Journal of Current Microbiology and Applied Sciences, 6(11), 2938-2946.

Mei, J. S., \& Chen, Y. H. (2007). Studies of different nutrients source of alpha amylase fermentation by Bacillus amyloliquefaciens . Journal Chemistry Engineering, 28, 1-8

Nelson, N. (1974). A Photometric adaptation of the Samogyi method for the determination of glucose. Journal of Biological Chemistry, 153(2),:375-380. Retrieved from http://citeseerx.ist.psu.edu/viewdoc/download ?doi=10.1.1.453.9073\&rep=rep1\&type 
Nwagu, T. N. \& Okolo. (2011). Extracellular amylase production of a thermotolerant Fusarium sp. isolated from Eastern Nigerian soil. Brazilian Archives of Biology and Technology, 54(4), 649-658.

Pelczar,M. J. (1988). Dasar-Dasar Mikrobiologi. Universitas Indonesia: Jakarta, Indonesia.

Sari, M. P. (2016). Isolasi bakteri Amilolitik termofilik dari sumber alir panas pacet Mojokerto dan pengujian aktivitas enzim amilase. Jurnal Biologi Universitas Andalas, 1(2), 166-171.

Schiraldi, C \& Rosa, M. D. (2002). The production of biocatalysts and biomolecules from extremophiles. Trend in Biotechnology, 20(12), 515521. https:// doi.org/10.1016/S01677799(02)02073-5

Streit, J.M., R.N, Jones., H.S, Sader., and Fritsche, T. R. (2004). Assessment of pathogen occurrences and resistance profiles among infected patients in the intensive care unit: Report from the SENTRY Antimicrobial Surveillance Program (North America, 2001). Int. J. Antimicrob. Agents, 24, 111-118.

Sudarhsan, S., Senthilkumar, S. and Ranjith, K. (2007). Physical and nutritional factors affecting the production of amylase from species of Bacillus isolated from spoiled food waste, African Journal of Biotechnology, 6(4), 430-435.

Svetlitchnyi, V. A., Kensch, O., Falkenhan, D. A., Korseska, S. G., Lippert, N., Prinz, M., Sassi, J., Schickor, A., \& Curvers, S. (2013). Single-step ethanol production from lignocellulose using novel extremely thermophilic bacteria. Biotechnol Biofuels, 6(1), 1-15. http://doi: 10.1186/17546834-6-31

Yang, C \& Liu, W. (2004). Purification and properties of a maltotriose-producing a-amylase from Thermobifida fusca. Enzyme Microbial Technology, 35, 254-260. 